\title{
History of Higher Education in Canada
}

\author{
NANCY M. SHEEHAN*
}

\begin{abstract}
This paper relates the changes that have occurred in historiography over the last couple of decades to the present state of writing on the history of higher education in Canada. The existing bibliography has laid the groundwork and the 'new' history offers the means by which the complex relationships between society and institutions of higher learning can be synthesized. A few examples of the kinds of questions that need to be asked and of some assumptions that need analysis are given. By looking at all phases of universities - professors, students, women, administrative and academic matters; by using quantitative as well as qualitative research techniques; by consulting government, church, local and business sources as well as university material; and by analyzing and critiquing the newer historians of higher education can help Canadians understand the traditions and mores of individual institutions as well as the collective impact of higher education on the society.
\end{abstract}

\section{RÉSUMÉ}

Ce travail relate les changements qui ont eu lieu en historiographie durant les dernières décennies et jusqu'à l'état actuel des écrits sur l'histoire de l'éducation supérieure au Canada. La bibliographie existante a servi de fondement et la "nouvelle" histoire offre un moyen de synthétiser les relations complexes entre la société et les institutions d'enseignement supérieur. L'étude inclut quelques exemples de questions et de présomptions qui méritent l'attention. En examinant la vie universitaire sous tous ses aspects - les professeurs, les étudiants, les femmes, les affaires académiques et administratives; en utilisant des techniques de recherche quantitatives aussi bien que qualitatives; en consultant le gouvernement, l'eglise, les sources locales et les affaires aussi bien que le matériel universitaire; et en analysant et en critiquant, les nouveaux historiens de l'éducation supérieure peuvent aider les Canadiens à comprendre les traditions et les coutumes des institutions individuelles aussi bien que l'impact collectif de l'éducation supérieure sur la société.

\footnotetext{
* Educational Policy and Administrative Studies, The University of Calgary
} 
Historical writing in Canada is influenced by and mirrors the concerns of the present. Certainly this has been the case over the last twenty years. Canadian History has gone through something of an upheaval, akin perhaps to the social changes that have been a part of the society since the 1960s. Instead of concentrating only on political, military and constitutional matters, historians in Canada began to show an interest in ethnicity, class, gender, and religion as variables in the historical story. They examined agriculture, settlement patterns and labour; delved into rural and urban lifestyles; and sought answers from unheralded groups in unimportant places.

Historians of education in Canada have been influenced as other historians by this "new" history, studying children, women and social, cultural and religious groups in relation to education. They are examining change in schooling and the processes of change - demography, geography, economics, politics and technology. A wide range of sources are being explored, such as textbooks, photographs, school architecture and local school records to name a few. This new educational history interprets, reasons and analyzes rather than narrates. No longer is educational history a tale of inevitable progress. No longer is it isolated, institutional history limited to schools and school buildings. No longer are educational historians missionaries using history as a device to dignify and inspire a new, self-conscious and understaffed profession. This is not to suggest that all "old" educational history is unworthy of the title history or that it made no contribution. Revisionism, however, has broadened the field and helped it become "one of the richest fields of critical inquiry." Excitement, controversy and self-analysis describe the mood of educational history, a mood which has placed it closer to mainstream history. (Wilson, From social control to family strategies, 1984 , p. 1)

Straddling both mainstream history and the history of education is the history of higher education. Since Rashdall's The universities of Europe in the middle ages, history of universities has been considered a legitimate activity for general historians. In the U.S. a number of studies have focussed on colleges and universities and their role in the social and intellectual development of the country. Veysey, Rudolph, Hofstadter and Metzger have led the way in examining the role of higher education. More recently, studies of individual institutions, histories which delve into one aspect of intellectual development, which look at denominational colleges, or women's institutions or professional schools have begun to revise, broaden and update these earlier studies. Although there are still institutionally subsidized university histories being written these are rapidly being outshone by the more scholarly activity of the newer breed of historians of higher education. (Hall, 1982, Frankfort, 1977, Diner, 1980, Williamson and Wild, 1976, Wechsler, 1977, Thelin, 1976, Conable, 1977, Allmendinger, 1975 and Burke, 1982)

Canadian historians have shown little interest in the history of our universities. 
There have been very few studies that match the breadth and analysis of either the earlier or the more recent U.S. studies. A tradition of intellectual and social history developed fairly early in the United States. (Curti, 1935) The popular interest in education, the proliferation of all kinds of colleges and universities, the early interest among members of the American Historical Association in the academic nature of history and the development of a number of prestigious research institutions helped that growth. (Higham, 1970) In Canada small, struggling institutions and professors with heavy teaching loads limited the field to more traditional political and military history. Even when conditions had improved in the 1960 s the social history that became popular was of the grass roots variety - of the poor, of women, and of immigrant groups. Universities, considered elitist institutions, did not fit this interest in the common people. The result has been that histories of Canadian universities have tended to be in-house histories, written by long time university administrators, using the minutes of board meetings, the memories of senior staff, and resulting in one-sided, institutional history. Often dependent on the universities' own archives and commissioned by the institutions themselves, the works focus on administrative and financial detail, on members of the board of governors and on facilities and buildings. Students, professors and intellectual developments are seldom addressed. Our university histories are institutional in approach, personal or biographical in style, progressive and laudatory in theme, sweeping in time span covered, and comprehensive with respect to topics. They suffer from both too much and too little information: too many issues are perused and each is given too little attention.

McGill University: for the advancement of learning by Stanley B. Frost (1980), a long time McGill administrator, is good institutional history. The author has used excellent, albeit traditional, historical sources, established a conceptual framework and written an interesting monograph. He clearly identifies the early problems, the evolution of an anglophone, protestant, professional institution, and the emergence of a vital, respected university suited to the needs and conditions of a growing Canada. Queen's University volume II 1917-1961: to serve and yet be free is a readable, well written account of that institution's growth. Including evidence from a variety of sources, focussing on all the parties involved (though not all to the same extent) including the principal and the administrators, the Board of Trustees and the benefactors, the alumni, the professors and the students, touching on matters relating to academic freedom and the teaching versus research debate, the author, a professor of history at Queen's as well as a Queensman, draws on material from government, institutional, private and media records. (Gibson, 1983) These two monographs highlight one of the aspects of our university histories - that they tend to be written by people associated for many years with the institution. It may be difficult to stand back and adopt a critical 
stance on an institution that has been one's academic and/or administrative home for many years. It may be equally difficult to distance oneself from the organization of the institution - from the administration and finance, the faculties and the board of governors.

A history of The University of Alberta 1908-1969 written by Walter H. Johns (1981), former president, is another example of institutional history. This volume has an abundance of names - of student leaders, of faculty, of board members and of administrators. These people come across as being gifted, relationships among the various bodies are serene, and problems are minimized because of sensible students and faculty and far-sighted administrators. There are, however, notable omissions. For example stress between Aberhart's Social Credit Government and the University is not addressed nor is the refusal of the Senate to award Aberhart an honorary degree. This kind of rosy haze is also evident in A. C. Bedford's well written account of The University of Winnipeg: a history of the founding colleges (1976). Surely a university in Winnipeg with a Methodist, Presbyterian, United foundation will have been affected by Winnipeg's volatile political and social history. The University however comes across as a promising, progressive, happy institution. Controversy, town and gown problems and analysis are lacking.

Also well written is Claude Bissell's Halfway up parnassus a personal account of the University of Toronto 1932-1971 (1974). Bissell's background in English, his intimate acquaintance with the university and his personal style make for an interesting, readable look at certain aspects of the institution. In no way does the author suggest he is writing history - he does not attempt to be comprehensive, he does not search out a variety of sources, and he does not feel compelled to mention every board and faculty member. And yet one learns a great deal about the University of Toronto community, particularly individual professors. Another popular, fast paced account and one that is also partly autobiographical is Herb Hamilton's Queen's, Queen's, Queen's (1977). One sided in concentrating on students; nostalgic in tales of school pranks, school characters and school games; and laudatory to Queen's and Queensmen, it is more of a personal story than the other academic volumes under discussion.

Religion has been central to university education in much of Canada and many of the written histories have focussed on theological issues and the interplay of religion and the growing interest in science and the social sciences. Charles Johnston's two volume edition of McMaster University $(1976,1981)$ provides a good example of the role of the Baptist Convention and the influence of American Baptist developments on this Canadian university. The main issues of modernism versus fundamentalism and metropolitanism versus regionalism are skillfully woven throughout the beginnings in Toronto, the transfer to Hamilton and the change to a secular institution. The story of McMaster includes the mistakes, the pitfalls and the problems caused by the ever-present Baptist Convention. It attempts to show the effects on the curriculum of non-academic matters but it does neglect the students. 
There have been several works published in the last dozen years that are broader than histories of single institutions. Robin Harris' A history of higher education in Canada 1663-1960 (1976), Laurence Shook's Catholic post-secondary education in English-speaking Canada: a history (1971) and Scholars and dollars: politics, economics, and the universities of Ontario 1945-1980 (1982) by Paul Axelrod each uses a different format and concentrates on a section of higher education in Canada. Of these Harris' has received the most attention, much of it critical. Basically he has produced descriptive history, in fact a catalogue of facts. Using university calendars at given focal time periods he attempts to correlate the curricula developments in each time period by means of a symbolic event chosen to help the reader understand the intellectual life of that era. A great deal of material over a broad expanse of time using only one primary source results in a very limited, non-explanatory, non-analytic history.

Shook's text is narrower in scope, concentrating on Catholic, English-language institutions - some thirty-two in all, including seminaries, junior colleges, colleges and universities. With a section devoted to each region of the country and a chapter to each individual institution the book is necessarily segmented and an overall picture of Catholic higher education is not produced. Neither is the reader able to discern distinctions among Catholic institutions or between these institutions and others, both religious and secular. Students, professors, issues of an academic nature and religious concerns are seldom addressed. Shook's volume is a catalogue, listing the beginnings and development of Catholic postsecondary institutions.

Scholars and dollars addresses the universities in Ontario from 1945 to 1980 exploring the impact of economic changes on them. It is a story of increasing government involvement, of a belief in economic returns for educational dollars and of a shift to additional professional preparation. According to Axelrod lack of economic blueprints, a dearth of informed curricula decisions and a larger student body resulted in haphazard, unplanned growth in the university sector as long as the dollars were flowing. The loss of the pot of gold as the economy slowed left the universities in straightened circumstances. This volume offers insight into the role of both government and the economy in the university. It is an example of the more limited studies that are necessary before we will be able to understand the interplay of universities and the society more clearly.

Margaret Gillett's We walked very warily: a history of women at McGill (1981.) is a pioneer attempt to write women into Canadian university history. The book concentrates on the principal, John R. Dawson, on administrative decisions and on finances. Although it is "new" history in its endeavor to focus on the student body, it has a tendency to be laudatory of the women, to emphasize progress over time and to be limited in its approach. Part of the difficulty with We walked very warily is that the only models of university history that existed in Canada ignored the students. Gillett's task was that much more onerous: to write women into a history that did not and does not exist.

Another recent study, like Gillett's, tackles a thematic issue in the history of 
Canadian universities. Donna Yavorsky Ronish's Sweet girl graduates: the admission of women to Canadian universities in the nineteenth century (Ph.D. thesis, Université de Montréal, 1983) deftly weaves into the story American and British influences on particular institutions, as well as spelling out the debate surrounding the education of women. Concentrating on the nineteenth century, she is able to set the debate over the admission of women in its economic, social, political and international contexts.

Perhaps the best example of university histories to date is John G. Reid's two volume work on Mount Allison University of Sackville, New Brunswick (1984). A Wesleyan institution with considerable American influence it began as an academy for boys, eventually incorporated a ladies' academy and a college level program offering degrees. Set in the context of the economic, political and religious background of the Maritimes, Reid shows the influence of a changing society on the college as well as attempting to analyze Mount Allison's influence on education in the Maritimes. He has done a superb job in successfully tracing the students (male and female) and identifying them by geographical origin, occupations of parents, religious backgrounds, community size, age and postMount Allison occupations. Finances, academic and administrative leadership and curriculum matters are all part of his analysis. Reid subjects his sources to practical as well as theoretical questions. Using a variety of original documents located in university, provincial, church and local archives, this study incorporates the most recent literature on the Maritimes, on industrialization, on women, on professionals and on other universities. It is institutional history, but Reid has used the "new" history approach - in his subject matter, in his methodology, in his sources and in his analysis.

One other volume deserves attention. A. B. McKillop's A disciplined intelligence: critical inquiry and Canadian thought in the victorian era (1979) examines the thought of Canada's major scientists, philosophers and clerics in relation to moral authority. Since many of these thinkers were associated with Canadian colleges and universities of the time period McKillop's volume does give us insight into the intellectual and moral concerns of some leading professors. It does help us understand the development of social gospel leaders and the continuing tendency of early 20th century Canadian thinkers to wed knowledge of the world and moral conviction. Although not a history of higher education, it is nonetheless intellectual history and an example of the kind of effort that would enhance our university histories.

\section{III}

The histories of universities that have been written to date have taken us part-way along the route that will help explain not only our intellectual growth but also the role of education, especially higher education in the country's development and direction. These histories for the most part have supplied us with the main events of each academic year or period; have given us a chronicle of facts 
upon which we can build an analysis; have listed the leading administrators and professors; and have recounted hours of wrangling over finances, buildings, presidential search committees and expansion plans. Some have done pioneer work on women, on students and on relating the college or university to the community. They have also identified and in many instances searched the various sources that are available, making the job of the future historian a little easier. With this kind of material available and with the canons of the new historiography at hand, the future for historians of universities in Canada is an inviting one.

For example, there is need for studies that show the influence on Canadian universities of changes and developments occurring eisewhere, particularly the United States and Great Britain, as well as changes in the Canadian society itself. Research that looks at the intellectual context of the colleges and at the ideas and the concepts that informed many societal issues is needed. The role of the institution as a social gatekeeper, as a mainstay of tradition must be considered. The very different roles of the small, denominational college and that of the federated university need exploration. An institution's effect on the surrounding community in relation to the size of the institution as well as the nature of the society should be examined. Continuity as well as change is important to the institution and to the community. Only when ideas such as these have been addressed will we have a better understanding of the relationship between the society and its institutions of higher learning.

In the 19th century most institutions in Canada were small, denominational colleges focussing on theology and liberal arts courses. Were they in essence different from institutions in Great Britain and the United States? Were they patterned on schools elsewhere or were they adapted to the Canadian clientele and climate? For example, John Dawson who made many trips to Britain to ascertain the reaction there to new ideas and to changes in higher education did not advocate the college system which was so much a part of Oxford and Cambridge. "From my own observations I cannot doubt that College residence is, even under the most favorable circumstances, most dangerous to the health, manners and morals of the students than to reside in respectable private houses." (Frost, 1980, p. 183) The English collegiate ideal was felt to be undesirable and abandoned at McGill. Was civilization and class status in the "new" world such that young men of college age could not be housed together? Was Dawson suggesting that Canadian students were too rough, too uncultured for residence life? And yet the federation at Toronto included residence colleges. For the most part these were based in a theological unit and had a denominational thrust. Perhaps McGill, protestant and professional in its educational atmosphere, was both too small and too broad to supply residence colleges which were either theologically or disciplinary based. Maybe without this kind of a philosophical ordering a residence college became more of a social than an academic organization.

When it came to women, however, McGill and Toronto reacted with different solutions and in each case these were in contrast to the pattern already established. Toronto accepted women but turned down a request for a separate college; McGill 
insisted on accepting women only with the proviso that a separate college would be established. (Brown, 1977, Gillett, 1981, pp. 63-72) Was there a lifestyle that suited man's intellectual endeavor but not woman's and that differed from one institution to another? Did women need the protection and surroundings of other women at McGill but not at Toronto? Was McGill afraid that women would be lost in the big institution whereas at Toronto they might be protected by denominational interests? Was it, as Joan Burstyn suggests for England, that women were very much subject to social control - a control which would be handled easier in a women's college at McGill and by individual denominations in Toronto's federation? (Burstyn, 1980, p. 11)

Small colleges must also be understood in terms of their context, which includes the general level of educational facilities, the regions in which they were located, levels of wealth, the relation of tuition expense to annual income, the structure of the labour market and the educational attitude of the particular denomination. In the early years small colleges tended to be hardly more than preparatory schools. However, in the context of the region, other institutions and the general educational level these colleges probably performed a valuable service albeit different from that of universities elsewhere. Perhaps small colleges helped young men make the transition from the rural to the urban area. Maybe they promoted upward mobility for youth through preparation for the ministry or for teaching. Did small colleges provide towns and villages with community leaders? Was the educational level higher in an area surrounding a small college than elsewhere in the region? Did this tend to raise the economic and social level of the area or was the region known for exporting its young to areas of promise?

One effect of a proliferation of small colleges may have been to make the large, urban, university more elite, more attractive to children of the power brokers. On the other hand such a proliferation may have meant competition for students and resources, preventing a strong, great university from developing. Certainly the Western provinces arguing for one provincial university used this reasoning. Concern for unity and worry over denominational factionalism were a part of the story. The precedent of the land grant institutions in the U.S. was also a factor. What difference to Alberta did the one provincial university make in comparison to the ten or eleven colleges found in Nova Scotia? Were educational expectations and levels higher or lower than elsewhere?

Universities and colleges have been called social gatekeepers. Little is known about the students who attended institutions of higher learning in Canada. We need to know who the students were - their ages, sex, religion and class. To ascertain if in fact the gatekeeping function is appropriate we should analyze the occupation and education of the parents, whether rural or urban residents and the type of high school attended. This information would allow us to profile the student body from one region to another, on the basis of size and over time. For example, does the student profile change as professional courses are added? What differences do depression and war make? Did the proportion of female students rise during both World Wars? Canadian institutions until quite recently have been class based and 
class biased institutions. (Porter, 1965; Porter, Porter and Blishen, 1982) But did the element of class vary from one college to another and was the social gatekeeping function one of social mobility or social control? Student admission data are available and computer techniques to compile and sort the data are possible. Reid in his study of Mount Allison has incorporated data on students' backgrounds to indicate who the students were and where they came from.

University graduates do not have to remain faceless. A follow-up in their lives and careers, and their attitude toward their alma mater evidenced by alumni activities and second generation attendance would give us a clearer picture of the institution's influence on its students. Did some institutions produce more successful business and professional people than others? Did government leaders and bureaucrats surface from one or more schools? Upper Canada College, a private, elite boys' preparatory school in Toronto, has been said over the years to have produced more business, government and professional leaders than any other institution. Recent work on the Imperial Order Daughters of the Empire suggests that the most common characteristic among the IODE executive in the 1900-1930 years was a husband who had attended Upper Canada College. (Sheehan, 1984) Did any institution at the postsecondary level have this kind of power? Queen's has such a reputation but without some analysis it remains unsubstantiated and misunderstood.

If universities are necessary to a country's continuing development and if university attendance is a must for upper and upper middle income/class status and if more and more dollars and more and more resources are being used by these institutions surely we need to know more about them. Is it the curriculum, the mix of students and faculty, the extra curricula activities, the contacts that give an institution a certain reputation, that attract students. The culture of an institution varies depending upon size, attitude toward research and the inclusion of professional faculties. In terms of faculty and students, which has the culture - the small, liberal arts school, a rich milieu in terms of friendship, cohorts, atmosphere, or the large research institution, isolated, sterile, with individuals working on esoteric research projects. Queen's, according to Neatby and Gibson, has a particularly loyal alumni. Why and what difference does this make to Queen's role in the community? Is there an optimal size that can combine both personal milieu and research quality/quantity?

The force of tradition must also be considered in analyzing our institutions. Certainly long time practices and attitudes can be difficult to change but some institutions have adapted more readily than others. The debate surrounding the admission of women highlights this point. McGill, an anglophone, Protestant, professional university in conservative, French, Roman Catholic Canada and with a principal very much a traditionalist on the role of women, was slow to open its door to women and insisted on a separate college for them. (Gillett, 1981; Frost, 1980) On the other hand Methodist Victoria and Mount Allison, Baptist Acadia and Presbyterian Queen's all accepted women earlier than McGill did and on an equal basis with the men. (Gillett, 1981, pp. 1-20, pp. 73-112) Did the 
denominational character of these latter institutions play a role in attitudes toward women? Many Quaker and Methodist private schools had offered girls an education in co-ed surroundings, believing that it facilitated "likemindedness," resulting in intra-faith marriages which insured continuity in the religious community. Perhaps if it was inevitable that some women were going to get a higher education it was preferable that they get it in a religiously controlled atmosphere. (Royce, 1978)

Were the Methodist, Baptist and Presbyterian institutions influenced by their American and Scottish counterparts and the trend in those countries to coeducation? Mount Allison in New Brunswick is a case in point. Founded as a Methodist institution, and run by Methodist ministers who had received their education and experience in the United States, Mount Allison graduated its first female student in 1875 - the first woman not only in Canada but also the Empire to be awarded a degree. Many American institutions had been co-educational for some time. Perhaps, as in the U.S. finances were crucial to the decision to admit women. As long as denominational colleges were proliferating, and the high school population remaining fairly stable, one method of increasing the enrollment was by admitting women students. Frederick Rudolph suggests that "Coeducation helped to save many one-time men's colleges of the small denominational type from being put out of business." (1965, p. 323)

This brings us to the question of admission practices. If admitting women was one way of increasing enrollment what other unwritten practices might determine either enrollment size or selectivity. How many and which applicants who fell short of stated admission standards received "conditional" acceptance? Did religion, ethnicity or father's wealth make a difference? When applications were plentiful did the development of selective mechanisms for entry skew the composition of the student body toward some ideal concept of what Canada should be like? Recent work on the history of education in the public systems suggest that English-only classes, British content and the stress on virtues like obedience, respect for authority, acceptance of one's place in life and hard work at the elementary level and a strong academic program at the secondary effectively controlled who would be Canada's leaders. (Stamp, The schools of Ontario, 1982; Wilson et al., Canadian education: a history, 1970) Did the colleges and universities reinforce these practices via selective admission criteria, service on provincial matriculation boards and a certain social atmosphere?

We need to know more about the establishment of professional faculties - e.g. engineering, medicine, law, dentistry and management. With a very practical component, and directed chiefly at the job market, the university moved from an ivory tower image to a role in the gross national product. Analyses of the integration of theory and practice, of research versus consulting, and of the university being directed by certification requirements would add to our understanding of continuity and change. The 'female' faculties of education, nursing, home economics, library science and social work need study. Were they an answer to the demographic scare and to social darwinism? Perhaps women 
could be isolated in these faculties, preventing real competition with men but at the same time preparing them for their life's work - raising the level of the position of wife and mother so that educated women would embrace it willingly and breed quickly enough to keep the society in balance. (Stamp, 1977)

Universities are called institutions of higher learning. This suggests an interest in academic subjects, in matters of the intellect. Unfortunately intellectual developments are not easy to discuss and except for McKillop's efforts there is a sparsity of material. The relationship between dogma and reason; the debate over evolution and social darwinism; progressive versus conservative policy; the capital punishment and abortion debates and finally the development of fifth generation computers are wide-ranging examples of intellectual problems that universities have been and are discussing. To what effect, one might ask. How do they influence curriculum decisions or public policy?

Universities are also places of academic freedom and of tenure. Yet seldom are these topics put in their historical contexts. John Clark Murray's problems at McGill over the education of women and Frank Underhill's difficulties at Toronto caused by comments on the British Empire are glossed over and do not elicit discussion on the merits and limitations of academic freedom. (Frost, 1980, Gillett, 1981; Bissell, 1974) How did this apply in religiously based institutions? What was the freedom of a professor to disagree with or to question matters of theology? Promotion, tenure requirements and increments differ from one university to another. Why? Is this tradition or the emulation of other institutions? How do criteria established for the traditional arts and science faculty affect the professional areas? The argument over what knowledge is of the most worth and whether areas in high demand by the workplace should receive differential treatment need to be put in perspective over time. Axelrod has made a start in this direction with his Ontario study.

The history of higher education in Canada is a wide open field. Not only have universities and colleges been poorly served by historiography, but other postsecondary institutions, such as normal schools, technical institutions and community colleges have been almost completely neglected. (Dennison, 1978, Calam, 1984, Hardy, 1981) We need studies of individual institutions; studies which link higher education to religious differences, regional pride, class struggle and national development; and studies that integrate education at all levels from the cradle to the grave. Only then will we be in a position to develop a synthesis on the role of higher education in the Canadian society.

This task will not be an easy one. Although most universities have some kind of an archives their records are sketchy, heavily administrative and not always located in the archives. For example, departmental and faculty records, if retained, are probably in those offices. The records of the registrar vary from one institution to another and over time. Personal information on students is often minimal, 
unorganized and lacking data essential to a student profile, like occupations of parents. Committee records necessary to understanding academic direction, tenure and promotion decisions, and research developments have seldom been made public.

This means that the historian has the onerous task of not only searching the archival material but also soliciting information from faculty offices, and other support units. The athletic office, the student council, and the various residences might provide needed material. The attitude toward athletics, the power of the student council and the differences among residences may tell us a great deal about the atmosphere, intellectual and social, of the institution. The student newspaper, records of various student societies and the activities and publications of the alumni office would also be of value. With this background material on hand the techniques of oral history could both solicit corroborating evidence and provide material to support committee and faculty decisions. Offices of Institutional Research offer opportunities to assist the researcher with more recent material. Their on-going functions of collecting, analyzing and comparing statistics, of monitoring change and of providing budgetary and planning data should give the historian access to sources and records that are more contemporary.

The historian of higher education, however, cannot depend solely on the records of the particular college or university. Relationships with the community, the provincial and federal governments and various religious bodies must be explored. Government records, newspapers and magazines and church documents are available and will help the historian analyze the role of the university as one of society's institutions. Its impact on the society and in turn the society's effect on the institution need to be explored from all angles. Although formal records must be searched, informal sources such as diaries, fiction, architecture and photographs can be informative.

Census data, birth, death and marriage certificates, real estate records, company personnel material and organizational membership lists are examples of the kinds of quantitative sources that can aid the historian of higher education in identifying students and alumni. The ability to computerize this material offers the potential to search large data bases; to separate unique characteristics of a particular student body from those that were typical of students in many institutions; and to indicate changes and trends in the make-up of students within individual universities, among institutions generally and over time.

If we are concerned to further our knowledge and understanding of the development and impact of universities in Canada then the opportunities are numerous. Such research would not only enhance our cultural and intellectual history generally but might also be useful to planners and administrators in helping them understand their own institution's traditions and mores. (Thelin, 1982, p. 173) 


\section{REFERENCES}

Allmendinger, D.F. Jr. Paupers and scholars: the transformation of student life in nineteenthcentury New England. New York: New York University Press, 1975.

Axelrod, P. Scholars and dollars: politics, economics, and the universities of Ontario 1945-1980. Toronto: University of Toronto Press, 1982.

Bedford, A.G. The University of Winnipeg: a history of the founding colleges. Toronto: University of Toronto Press, 1976.

Bissell, C. Halfway up parnassus: a personal account of the Univerity of Toronto 1932-1971. Toronto: University of Toronto Press, 1974.

Brown, M.J. "A disposition to bear the ills ...': rejection of a separate college by University of Toronto women." Canadian Women's History Series, Toronto: OISE, 1977.

Burke, C.B. American collegiate populations: a test of the traditional view. New York: New York University Press, 1982.

Burstyn, J.N. Victorian education and the ideal of womanhood. London: Crook Helm, 1980.

Calam, J. "Teaching the teachers: establishment and early years of the B.C. provincial normal schools," B.C. Studies, 1984, 61(1), 30-63.

Conable, C. Women at Cornell: the myth of equal education. Ithaca, N.Y.: University of Cornell Press, 1977.

Curti, M. The social ideas of American educators. New York: Charles Scribner's Sons, 1935.

Dennison, J.D. University transfer programs in the community college. The Canadian Journal of Higher Education, 1978, 8(2), 27-36.

Diner, S. A city and its universities: public policy in Chicago, 1892-1919. Chapel Hill: University of North Carolina Press, 1980.

Frankfort, R. Collegiate women, domesticity and career in turn-of-the century America. New York: New York University Press, 1977.

Frost, S.B. McGill University: for the advancement of learning, volume 1, 1801-1895. Montreal: McGill-Queen's University Press, 1980.

Gibson, F.W. Queen's University volume II 1917-1961: to serve and yet be free. Kingston \& Montreal: McGill-Queen's University Press, 1983.

Gillett, M. We walked very warily: a history of women at McGill. Montreal: Eden Press Women's Publications, 1981.

Hall, P.D. The organization of American culture: private institutions, elites, and the origins of American nationality. New York: New York University Press, 1982.

Hamilton, H. Queen's, Queen's, Queen's. Kingston: Alumni Association of Queen's University, 1977.

Hardy, J.S. Training third class teachers: a study of the Ontario county model school system, 1877-1907, Ph.D. thesis, University of Toronto, 1981.

Harris, R.S. A history of higher education in Canada, 1663-1960. Toronto: University of Toronto Press, 1976.

Higham, J. The study of American intellectual history in Writing American history: essays on modern scholarships, ed. Higham, John. Bloomington: Indiana University Press, 1970.

Hofstadter, R. Academic freedom in the age of the college. New York: Columbia University Press, 1955.

Johns, W.H. A history of The University of Alberta 1908-1969. Edmonton: The University of Alberta Press, 1955.

Johnston, C.M. McMaster University: vol. 1 the Toronto years. Toronto: University of Toronto Press, 1976. 
Johnston, C.M. McMaster University: vol. 2 the early years in Hamilton 1930-1957. Toronto: University of Toronto Press, 1981.

McKillop, A.B. A disciplined intelligence: critical inquiry and Canadian thought in the victorian era. Montreal: McGill-Queen's University Press, 1979.

Metzger, W.P. Academic freedom in the age of the university. New York: Columbia University Press, 1955.

Porter, J. The vertical mosaic: an analysis of social class and power in Canada. Toronto: University of Toronto Press, 1965.

Porter, J., Porter, M., \& Blishen, B. et al. Stations and callings: making it through the school system. Toronto: Methuen Publications, 1982.

Rashdall, H. The universities of Europe in the middle ages, New Edition, edited by F.M. Powicke and A.B. Emden. Oxford: Oxford University Press, 1936.

Reid, J.G. Mount Allison University: a history to 1963 (in two volumes) Toronto: University of Toronto Press, 1984.

Ronish, D.Y. Sweet girl graduates: the admission of women to Canadian universities in the nineteenth century, Ph.D. dissertation, Université de Montréal, 1983.

Royce, M.V. Education for girls in quaker schools in Ontario. Atlantis, 1978, 3(1), Part 1, 181-192.

Rudolph, F. The American college and university: a history. New York: Vintage Books, 1965.

Sheehan, N.M. 'Teasippers or crusaders': The IODE as a women's organization, paper read at the Canadian Historical Association annual meeting, June, 1984.

Shook, L.K. Catholic postsecondary education in English-speaking Canada: a history. Toronto: University of Toronto Press, 1971.

Stamp, R.M. Teaching girls their 'God given place in life': the introduction of home economics in the schools. Atlantis, 1977, 2(2), 18-34.

Stamp, R.M. The schools of Ontario. Toronto: University of Toronto Press, 1982.

Thelin, J.R. The cultivation of ivy: a saga of the college in America. Cambridge, Mass.: Schenkman Publishing Co., 1976.

Thelin, J.R. Higher education and its useful past: applied history in research and planning. Cambridge, Mass.: Schenkman, 1982.

Veysey, L. The emergence of the American university. Chicago. University of Chicago Press, 1965.

Wechsler, H.S. The qualified student: a history of selective college admission in America. New York: John Wiley \& Sons, 1977.

Williamson, H.F., \& Wild, Payson S. Northwestern University: a history, 1859-1975. Evanston, 11l.: Northwestern University, 1976.

Wilson, J.D., et al. (eds.) Canadian education: a history. Toronto: Prentice-Hall, 1970.

Wilson, J.D. From social control to family strategies: some observations on recent trends in Canadian educational history. History of Education Review, 1984, 13(1), 1-13. 